Review Article

\title{
A Conceptual Review of Abhyanga and its Cosmetic Benefits
}

\author{
Shrutijhawar
}

$2^{\text {nd }}$ Year PG, Dept. of PG Studies in Kayachikitsa, Sri Sri College of Ayurvedic Science and Research, Bangalore. DOI: https://doi.org/10.24321/2394.6547.201906

I $\quad \mathbf{N} \quad \mathbf{F} \quad \mathbf{O}$

E-mail Id:

shruti.jhawar1995@gmail.com

Orcid Id:

https://orcid.org/0000-0002-1701-8835

How to cite this article:

Jhawar S. A Conceptual Review of Abhyanga and its Cosmetic Benefits. J Adv Res Ayur Yoga Unani Sidd Homeo 2019; 6(3\&4): 1-3.

Date of Submission: $2019-12-10$

Date of Acceptance: 2020-01-25

\section{$\begin{array}{llllllll}\mathbf{A} & \mathbf{B} & \mathbf{S} & \mathbf{T} & \mathbf{R} & \mathbf{A} & \mathbf{C} & \mathbf{T}\end{array}$}

Ayurveda is a science of life that from time immemorial has served the purpose of health and beauty to humanity. It has abundance of practices and procedures that when practiced regularly, not only benefit the human health but are holistic to the environment and community. A few of these measures are grouped under Dinacharya, one among which is Abbhyanga. Abhyanga, when followed regularly renders various benefits to the body. The mode of action of the same has been clearly explained by Acharya Sushruta, in chapters of Dhamanee Shareera and Twak Shareera. The Tiryak-Gata Dhamanee helps to transfer, metabolize and utilize the Abhyanga Dravya with the help of other components of the Twak, which are then projected by Avabhasini layer of Twak, along with the other benefits of Abhyanga. This regular use of Abhyanga is being advocated here in order to re-establish the importance of Dinacharya, as well as reduce the burden of cosmetics in a person's life.

Keywords: Abhyanga, Twak, Dhamanee, Cosmetics

\section{Introduction}

Rome wasn't built in a day. Similarly health and beauty cannot be expected to be achieved with one day's effort. To a person looking at us, the index of our health is expressed by our skin. It is the reflection of our body's internal health. If the health of our body is maintained, it programs the skin to be beautiful. But today, the idea of cosmetics has twisted the definition of beauty by introducing products which, mask the person into looking beautiful. Cosmetic industry today is one of the highest grossing industry, expected to garner more than 429.8 billion by the year 2022. ${ }^{1}$ The advent of newer products, by the second, makes it the need of the hour to embrace our roots further more. One such technique is that of Abhyanga told as a part of Dinacharya. It is a procedure when followed as routine, would not only make the skin better but improve the overall health indeed. It could be the answer to major health and cosmetic needs today.

\section{Abhyanga as a Cosmetic}

In order to understand the effects of Abhyanga, it is important to understand the following factors first. It includes:

\section{Twak Shareera}

The Ayurvedic assessment of Twak includes factors like:

- Dosha: ${ }^{2}$ Vataja, Pittaja, Kaphaja or having mixed features.

- Desha: ${ }^{3}$ Akashiya, Vayaviya and the like (i.e., having Bhautika features).

- Garbhavakranti: ${ }^{4}$ Twak, is the Ksheerasantaanika, creamy layer after a process of Paaka, formed from the Shukra-shonita Samayoga during Garbhaavakranti. ${ }^{1}$ 
This forms the criteria of assessment to us when we examine a patient in the OPD. Twak of the patient is not only affected by his environment and habits today but also influenced by the Shukra, Shonita, Garbhaashaya, Matru-Ahaara and Vihaara. Thus, when all these factors are catered to, resultant Twak can be expected to be healthy.

Twak is formed as 7 layers, of which Avabhaasini is the first. ${ }^{5}$ The layer that reflects what lies beneath it is called Avabhaasini. This layer acts like a mirror projecting the Pancha-Chhaya ${ }^{6}$ and sarva-varnas ${ }^{7}$ attributed to it, which are Praakrutik to the person.

\section{Dhamanee Shareera}

How does Abhyanga, the topical application of oil, aid 'Swaasthya'? The answer to this lies in Twak Shaareera ${ }^{8}$ and Dhamanee Shaareera ${ }^{9}$ as explained by Sushruta Acharyaa.

Abhyanga Dravya applied over the skin enters the deeper layers of Twak with the help of Twak Bhraajaka Pitta, Dehaagni and Veerya of the Abhyyanga dravya. ${ }^{10}$ Once in the Twak, their action is not limited to that of the Twak only. The Abhyanga Dravya reaches the deepest Dhatus with the help of Dhamanees, that is, Tiryakgata-Dhamanees which begin from the Nabhi. They re-divide into numerous smaller Dhamanees till they reach the Romakupas in the Twak. Here they act as a channel of transportation of the Abhyanga Dravyas from the Twak to various places in the body. ${ }^{11}$

The extent of reach of the Abhyanga Dravya can be appreciated as follows:

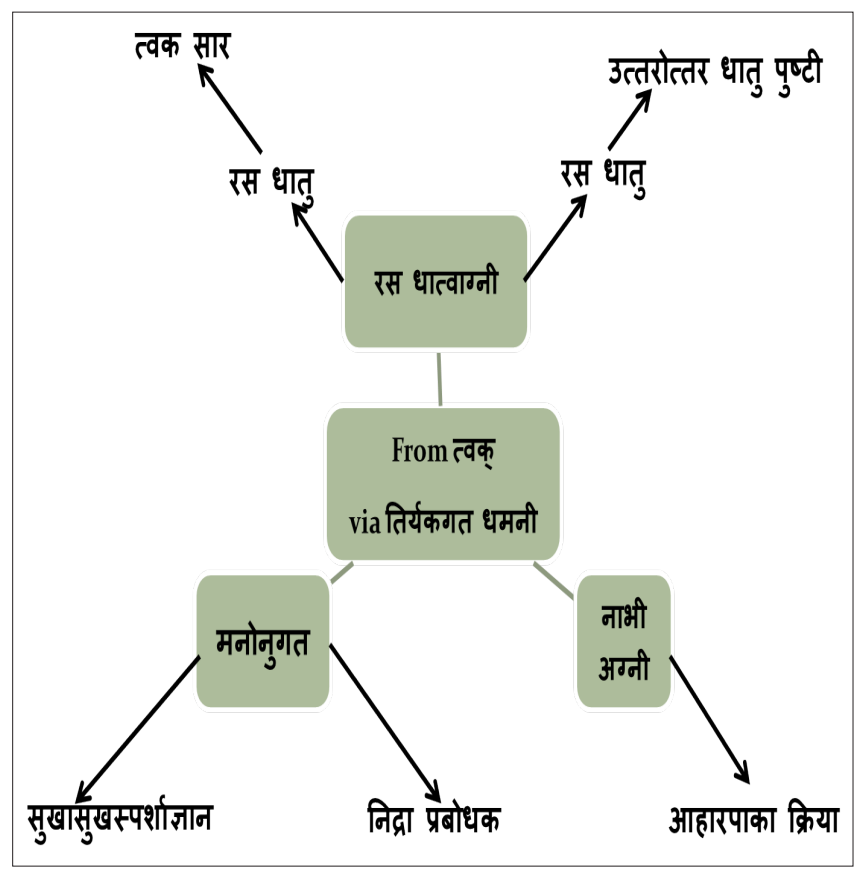

- Via the Tiryakgata-Dhamanees, the Dravya travels to the Nabhi (Udbhavasthana of the Dhamanees). NABHI being the Sthaana for agni, ${ }^{12}$ the Abhyanga Dravya has its effect on agni too. It enhances the Agni hence helping in Aaharapaka Kriya. This results in the benefits like-Tushti Prasad, Pushti, Dardhya-Krut.

- From the Nabhi, these Dravyas can travel to the Hridya via the Urdhwagata-Dhamanees. ${ }^{13}$ Here they have effect on the Rasa Dhatu, Hridaya being a Sthana for it. ${ }^{14}$ This has dual benefits of making the person Rasa Sara or Twaksara ${ }^{15}$ and also helping in Uttarottara Dhatupushti. ${ }^{16}$ This results in benefits of Sutvak, JaraShrama Hara, Ayu Pradana.

- Also, as Twak is a Sparshanendriya, ${ }^{17}$ Abhyanga over Twak stimulates Manas. This, in turn, causes Sukhaasukha Sparshagnyan and Nidra Prabodhana..$^{18}$

- Hence, it can be understood that the process of Abhyanga with the help of the Tiryak-Gata Dhamanee nourishes the skin externally and also the entire body from within.

\section{Discussion}

The benefits of Abhyanga, as stated by various Acharya, are: Sutvak (good skin), Susparsha (soft or healthy on touch), Priya darshana (pleasing in appearance), alpa Jara and so on (anti-ageing), and the like. The cosmetic industry flourishes by using the principles of procedures like Abhyanga, Udwartana, Utsadana, Anjana ${ }^{19}$ and the like to produce products like creams, moisturizers, sunscreens, day creams, night creams, face packs and so on. The modern science also accepts the benefits of massage in overall systemic and cosmetic benefits, but lacks the principles and medications of Ayurveda. It is hence needed that we elaborate the benefits of Dinachrya, and especially Abhyanga to the world.

\section{Conclusion}

All these factors put together make a person overall Swastha. Therefore, even if Abhyanga is done over the Twak locally, it manifests into the extensive nourishment of the body. The verse from Ashtanga Hridaya regarding the benefits of Abhyanga denotes that they are never limited to the Twak alone. It has the potency to make the person Swastha when practiced regularly and suitably. ${ }^{20}$ Then, we need not resort to the option of makeup to conceal our shortcomings.

\section{Conflict of Interest: None \\ References}

1. https://www.alliedmarketresearch.com/cosmeticsmarket.

2. Sushruta, Dalhana and Yadavji Trikamji Acharya, Sushruta samhita. Varanasi: chaukhaba Sanskrit sansthan; 2015; 361.

3. Sushruta, Dalhana and Yadavji Trikamji Acharya, Sushruta samhita. Varanasi: chaukhaba Sanskrit 
sansthan. 2015; 355.

4. Sushruta, Dalhana and Yadavji Trikamji Acharya, Sushruta samhita. Varanasi: chaukhaba Sanskrit sansthan. 2015; 361.

5. Sushruta, Dalhana and Yadavji Trikamji Acharya, Sushruta samhita. Varanasi: chaukhaba Sanskrit sansthan. 2015; 355.

6. Achaarya Agnivesha. Charaka Samhitha. Vaidya Jadavji Trikamji Acharya, editor. Reprint 2008 ed. Varanasi: Chaukambha Orientalia. 2008; 365.

7. Achaarya Agnivesha. Charaka Samhitha. Vaidya Jadavji Trikamji Acharya, editor. Reprint 2008 ed. Varanasi: Chaukambha Orientalia. 2008; 355.

8. Sushruta, Dalhana and Yadavji Trikamji Acharya, Sushruta samhita. Varanasi: chaukhaba Sanskrit sansthan. 2015; 355.

9. Sushruta, Dalhana and Yadavji Trikamji Acharya, Sushruta samhita. Varanasi: chaukhaba Sanskrit sansthan. 2015; 384.

10. Sushruta, Dalhana and Yadavji Trikamji Acharya, Sushruta samhita. Varanasi: chaukhaba Sanskrit sansthan. 2015; 385.

11. Sushruta, Dalhana and Yadavji Trikamji Acharya, Sushruta samhita. Varanasi: chaukhaba Sanskrit sansthan. 2015; 385.

12. Achaarya Agnivesha. Charaka Samhitha. Vaidya Jadavji Trikamji Acharya, editor. Reprint 2008 ed. Varanasi: Chaukambha Orientalia. 2008; 517.

13. Sushruta, Dalhana and Yadavji Trikamji Acharya, Sushruta samhita. Varanasi: chaukhaba Sanskrit sansthan. 2015; 384.

14. Achaarya Agnivesha. Charaka Samhitha. Vaidya Jadavji Trikamji Acharya, editor. Reprint 2008 ed. Varanasi: Chaukambha Orientalia. 2008; 250.

15. Achaarya Agnivesha. Charaka Samhitha. Vaidya Jadavji Trikamji Acharya, editor. Reprint 2008 ed. Varanasi: Chaukambha Orientalia. 2008; 287.

16. Achaarya Agnivesha. Charaka Samhitha. Vaidya Jadavji Trikamji Acharya, editor. Reprint 2008 ed. Varanasi: Chaukambha Orientalia. 2008; 514.

17. Sushruta, Dalhana and Yadavji Trikamji Acharya, Sushruta samhita. Varanasi: chaukhaba Sanskrit sansthan. 2015; 385.

18. Sushruta, Dalhana and Yadavji Trikamji Acharya, Sushruta samhita. Varanasi: chaukhaba Sanskrit sansthan. 2015; 385.

19. Vagbhatta, Arunadatta and Murthy S. Ashtanga Hridaya. Varanasi, U.P: Chowkhamba Krishnadas Academy: 2000; 23.

20. Vagbhatta, Arunadatta and Murthy S. Ashtanga Hridaya. Varanasi, U.P: Chowkhamba Krishnadas Academy: 2000; 23. 